This is the post print/pre print version of the article, which has been published in Organization Studies . 2018, 39 (11), 1601-1624.https://doi.org/10.1177/0170840617717093

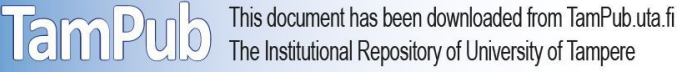

\title{
The Emergence of Transformative Agency in Professional Work
}

\section{Tiina M Tuominen and Mikko H Lehtonen}

\section{Tiina M Tuominen}

Aalto University School of Science and Hanken School of Economics, Finland

\section{Mikko H Lehtonen}

Aalto University School of Science, Finland

\section{Corresponding author:}

Tiina Tuominen, Department of Industrial Engineering and Management, Aalto University School of Science, Maarintie 8, FI-00076 Aalto, Finland.

Email: tiinamtuomi@gmail.com

\section{Abstract}

Even though transformative agency is widely discussed in organization studies, recent conceptualizations provide little information about the dynamics through which transformative agency emerges at the individual and collective levels, or how these levels influence one another in a particular context. We employ critical realist theories to explore transformative agency in different types of temporary service development groups in 
professional service organizations. Our study suggests how individuals' transformative agency emerges from their reflexivity and bargaining power conditioned by resource distributions, and how collective agency subsequently emerges from different combinations of these individual properties in temporary agentic groups. The study clarifies the interplay between the individual and collective levels of agency, and supports further multilevel studies on transformative agency in organizational change.

\section{Keywords}

Transformative agency, reflexivity, morphogenesis, professional service firm, collective agency, synchronic emergence, diachronic emergence

\section{Introduction}

The concept of agency is used in organization studies to explain organizational members' ability to purposively pursue continuity or transformation of their social contexts. This concept draws attention to the relations between individuals and their social contexts, particularly to the way structures and cultures condition action (Archer, 2012; Emirbayer \& Mische, 1998; Lawrence \& Suddaby, 2006). Researchers have devoted considerable effort towards explaining individuals' ability to purposefully transform the structures in which they are embedded (Battilana, 2006; Garud, Hardy, \& Maguire, 2007), which we refer to as transformative agency.

Previous studies have suggested that transformative actions can occur throughout an organization, leading to a variety of changes in the organization's goals, practices and outcomes (Caldwell, 2005; Howard-Grenville, 2005; Orlikowski, 1996). Any organizational member may be capable of transformative action, even though agency 
differs according to each individual's history, position and structural context (e.g. Battilana, 2006; Dorado, 2005; Mutch, 2007; Whittington, 1992).

While previous studies have provided substantial knowledge about the conditioning of individual agency, transformative agency as a collective construct - as collective potential - is generally unpacked or treated as the simple aggregate potential of individuals. Most studies focus on the actions of individuals (Battilana \& D'Aunno, 2009; Emirbayer \& Mische, 1998) or groups of similarly positioned individuals who compete with other agents when advancing their projects (Herepath, 2014). However, dispersed and collaborative change processes, which involve a number of different actors, are becoming increasingly common, and are considered an important research topic (Bridwell-Mitchell, 2016; Garud \& Karnøe, 2003; Hargadon \& Bechky, 2006; Hargrave \& Van de Ven, 2006). To better understand how transformative agency emerges within such diverse groups, they need to be treated as complex, stratified and intersecting entities that influence their members and can achieve more than the aggregate effects of their members (Elder-Vass, 2010). This points to the need to analyse the relations between individuals within agentic groups (Kozlowski \& Klein, 2000; Morgeson \& Hofmann, 1999).

We apply critical realism to research the emergence of transformative agency in professional service firms, in which ordinary organizational members form temporary transformative agentic groups to address particular development needs. Critical realist approaches are particularly fruitful in detailing the interplay of entities at different levels and layers of reality. We compare and combine insights from Archer's (1995) morphogenetic model, which addresses the emergence of agency over time (diachronic 
emergence), and Elder-Vass's model of synchronic emergence (2005, 2010), which addresses the layered nature of collective phenomena at a single moment in time. We use this conceptualization to study how resources, the properties of individuals and their relations within a group interact in the emergence of agency in different types of development groups. The paper clarifies agency as a multilevel phenomenon relationally and dynamically constituted in organizations, and supports future research on collective transformative agency in organizational settings.

\section{Multilevel View on Agency in Organizations}

Studies of practice change, institutional work and institutional entrepreneurship use the concept of agency to explain purposive action. Depending on the underlying theory, researchers link agency either to the actors' orientation towards maintaining or changing the situations they face (Emirbayer \& Mische, 1998; Howard-Grenville, 2005; Smets \& Jarzabkowski, 2013), or to their power to make a difference (Burkitt, 2016; Giddens, 1984; Llewellyn, 2007). Both conceptualizations connect agency intimately to the actor's structural and cultural contexts, which influence whether the actor pursues transformation or continuity. Previous studies have suggested that unstable macro-level conditions, structural tensions and a plurality of logics provide opportunities for change (e.g. Dorado, 2005; Levina \& Orlikowski, 2009). The occupation of dominant positions provides resources for change, while actors in marginal positions are likely to be motivated to pursue change (Battilana, 2006). In addition to these direct influences, individuals' personal histories, or their institutional biographies, explain why some people are oriented towards change while others act habitually (Lawrence, Suddaby, \& Leca, 2011). 
Recent studies have also called for more research on how meso-level issues, such as group membership, influence individual agency (Dorado, 2013). As individuals rarely transform their contexts alone, concepts such as collaborative institutional agency (Bridwell-Mitchell, 2016), collective institutional entrepreneurship (Wijen \& Ansari, 2007) and distributed agency (Garud \& Karnøe, 2003) have generated attention in institutional theory, for example. Groups can not only integrate and mobilise resources for a common cause (Desa, 2012; McCarthy \& Zald, 1977), they can also influence individuals' orientations, creating a favourable context for transformative action (Dorado, 2013).

However, compared to other constructs in organization studies, agency at a collective level remains loosely defined-how collective agency emerges from the interaction between individual-level properties, for instance, is unclear (see Morgeson \& Hofmann, 1999). Whereas recent institutional theories advance an understanding of agency at the individual level, their individualist assumptions have been challenging to group-level studies (Dorado, 2013). Practice studies address collective practices, but they generally assume a duality of structure and agency (Feldman \& Orlikowski, 2011) that prevents the analysis of the structures and agency of individuals and groups as - at least analytically and temporally—separable and interacting entities (Herepath, 2014).

We suggest that these multilevel relations can be conceptualized using critical realist approaches. These approaches assume that different entities, such as individuals, groups, institutions and societal structures, have emergent properties or powers through which they exert causal effects on the world in their own right, rather than acting as a mere sum of their parts (Elder-Vass, 2005; Fleetwood, 2005). This view enables the analysis of 
complex relations, including the effects of higher-level entities on lower-level entities, as well as the way collective phenomena emerge from lower-level properties (Kozlowski \& Klein, 2000; Vincent \& Wapshott, 2014). Therefore, critical realist approaches can provide richer explanations of agency than approaches based on methodological individualism, holism or on the duality of structure (Archer, 1995).

Furthermore, critical realists assume that properties such as transformative agency can exist without being exercised; powers may be possessed, exercised or actualised (O’Mahoney \& Vincent, 2014, p. 8). In line with this reasoning, we treat transformative agency as human potential for purposeful transformative action, separating it from situated transformative action - the realisation of that potential in social situations. Next, we discuss how the theories of Archer $(1995,2000,2012)$ and Elder-Vass $(2005,2010)$ help us develop a multilevel view on the emergence of agency.

\section{Emergence of agency over time: Archer's morphogenetic model}

Archer suggests that social reproduction or change is a consequence of the interplay between the emergent properties of social structure, culture and people. These properties develop interdependently, but have their own effects on society; thus, they should be analytically separated (Archer, 1995). She argues that while structures emerge as consequences of human action, existing structures present objective constraints for current agents, and are difficult to change rapidly. Social change is a cyclical process involving three parts: at time T1-T2, existing structures and cultures condition the interpretations and actions of agents by shaping the situations in which they find themselves. At time T2-T3, agents interact to pursue their projects, activating both structural and personal properties. Structural elaboration (morphogenesis) or 
reproduction (morphostasis) at time T3-T4 are consequences of these interactions, and provide the beginning (T1-T2) for a new morphogenetic cycle.

This view presents agency as an agent's social and relational property, which emerges in relation to both the structural contexts and human qualities in morphogenetic processes. Archer focuses on large sociological processes, and always defines 'an agent' as a collectivity, consisting of similarly positioned people in a society's distribution of resources (Archer, 2000:, p. 261). This distribution pre-groups agents into groups with different opportunity costs and benefits from certain actions, which influences their vested interests and bargaining power (Archer, 1995). Similarly positioned people who are not organised for collective action are labelled 'primary agents'. Some of them become organised as 'corporate agents'. Only corporate agents have a say in the morphogenetic process, even though primary agents also generate aggregate effects. The transformative power of corporate agents arises from their ability to articulate shared interests and organise for collective action (Archer, 1995; Archer \& Donati, 2015).

Even though structures condition agents' actions, Archer suggests that people can resist, repudiate or circumvent structural conditioning because their emergent properties are only partially of social origin. Reflexivity, which arises from individuals' personal identities, plays a crucial role in her theory. It is defined as a mental ability: 'our power to deliberate internally upon what to do in situations that were not of our making' (Archer, 2003, p. 342). Reflexivity is involved when actors interpret situations and form agentic projects, thus mediating the influence of structure on agentic action (Archer, 1995, 2003; Delbridge \& Edwards, 2013; Herepath, 2014). Unlike other theories (e.g. Giddens, 1984), Archer suggests that reflexivity can develop into different modes depending on 
individuals' life experiences, which explains individuals' different tendencies towards continuity or transformation (Delbridge \& Edwards, 2013). Persons living in continuous contexts are likely to develop a 'communicative reflexive mode': They tend to favour continuity and discuss decisions with other people. People living in discontinuous contexts are likely to develop an 'autonomous reflexive mode', meaning they search for future opportunities and make decisions independently. Incongruous contexts may lead to a 'meta-reflexive mode' - a critical perspective on social contexts and one's own reflexivity-which can lead to either direct action or withdrawal, or 'fractured reflexivity', in which it is difficult to sustain projects (Archer, 2003, 2012).

This theory indicates that whether agents orient themselves towards reproductive or transformative projects depends on both their structural positions and reflexive deliberations (see also Emirbayer \& Mische, 1998). However, the realisation of their projects depends on their capability to organise for collective action, and on the interests and resources of other agents. In later works, Archer and Donati (2015) argue that group members' reflexive orientation towards collective outcomes is important for a group to reach its goals and generate relational good (see also Mrozowicki, 2010). Nevertheless, social interactions between groups typically lead to compromises and unanticipated consequences, advancing either structural elaboration or continuity. Structural elaboration changes resource distributions, and leads to the re-grouping of agents. This process, in which agency itself is transformed, is labelled double morphogenesis (Archer, 1995).

In organization studies, Archer's approaches are suggested to contribute to the development of relational approaches and broader ontologies (Mutch, Delbridge, \& 
Ventresca, 2006; Seidl \& Whittington, 2014). The morphogenetic model has been applied, for example, to analyse interorganizational exchange relations (Vincent, 2008), strategy making in healthcare organizations (Herepath, 2014) and the use of IT in organizations (Mutch, 2010a). Archer's typology of reflexivity aids in understanding the paradox of embedded agency; it is linked to individuals' temporal orientations (Delbridge \& Edwards, 2013). Fractured personal histories, movements between fields and marginal or autonomous positions (Delbridge \& Edwards, 2013; Mutch, 2007), as well as contextual conditions such as codification, the increased availability of information (Mutch, 2010a, 2010b) and the existence of multiple logics (Delbridge \& Edwards, 2013; Edwards \& Meliou, 2015) tend to foster autonomous reflexivity, which is linked to projective, transformative actions. Actors' embeddedness in a dominant logic (Edwards \& Meliou, 2015) and close relationships within communities of practice (Mutch, 2010b) are more likely to foster communicative reflexivity, which is linked to stabilitypreserving actions.

We apply Archer's approach to model how transformative agency develops as a consequence of changes in resource distributions, mediated by reflexivity. Archer's model also provides a holistic explanation of agentic action by discussing both reflexive orientations/interests and bargaining power, which explains agents' potential to both pursue and implement projects (Battilana, 2006; Daudigeos, 2013; Llewellyn, 2007). However, Archer does not offer much insight into the internal dynamics of agentic groups. Agency is viewed as a shared unit property, comprising similar properties of members (Kozlowski \& Klein, 2000): The formation of primary agents is described as a top-down process, whereby individuals are involuntarily placed in social structures, whereas the emergence of corporate agents is a bottom-up process in which organized 
groups emerge from interactions between primary agents (Archer, 1995). Even though the members can inhabit a range of different roles, Archer does not discuss how these differences contribute to corporate agency, and individual actors' transformative potential is limited to personifying their roles and moving between roles (Archer, 1995, 2000).

This description appears to be too simplistic due to organizational members' inclusion in several social systems (e.g. Drazin, Glynn, \& Kazanjian, 1999). As reflexive human beings, they bring interests and resources from these systems into the focal organization, where they influence their interpretations, interests and bargaining power (Delbridge \& Edwards, 2013; Leca \& Naccache, 2006; Levina \& Orlikowski, 2009). Thus, individual actors can have idiosyncratic effects in change processes (Garud \& Karnøe, 2003; Howell \& Higgins, 1990); and, as 'corporate agents', organisations and organisational sub-groups should be viewed as stratified entities whose members share some interests and resources that motivated them to form corporate agents but are, in other respects, differently positioned. Thus, we suggest complementing Archer's view with another view on emergence, discussed by Elder-Vass (2005, 2010).

\section{Internal stratification of agentic groups: Elder-Vass' synchronic emergence}

Elder-Vass views the morphogenetic model as one of diachronic emergence, which explains how different entities influence one another over time, and complements it with a model of synchronic, relational emergence, which is defined as 'synchronic relation amongst the parts of an entity that gives the entity as a whole the ability to have a particular (diachronic) causal impact' (2005, p. 321). We use this model to suggest how individual-level agency emerges from relations between an individual's mental and physical properties, while corporate agency emerges from relations between group 
members. A group's ability to coordinate and combine the diverse contributions of its members has a significant impact on the effect the group can make. Further, Elder-Vass suggests that group processes also influence group members (see also Archer, 1995, p. 184). This multilevel view on agency is summarized by Elder-Vass:

When individuals become parts of social groups, they do not lose the powers they have as individuals, but those powers are channelled and constrained as a result of the relations those individuals now have with others in the group. The consequence is that this group of people, structured as it now is by the relations between those people, has as a social entity powers that none of the individuals would otherwise have. [2007, p. 475]

Figure 1 summarizes how we apply the theories of Archer and Elder-Vass to study transformative agency in temporary development groups, which are typical in many organizational change processes. The proposed model suggests that past structures diachronically shape individuals' agentic properties via resource distributions. Thus, at time T1-T2, reflexive orientations and bargaining power are likely to differ between organizational members with different positions and life experiences (Battilana, 2006); at the same time, these properties synchronically influence their agency. These differences and similarities may inspire actors to form groups to pursue common interests at time T2T3. Collective transformative agency emerges synchronically from relations between group members, thus leveraging, integrating and enhancing individual-level properties. This collective potential is actualized when group members interact with one another and with other agents when pursuing their interests. The actual causal influence of a group- 
the reproduction or elaboration of the group's context at time T3-T4-is an unanticipated consequence of this interaction. Structural elaboration diachronically changes the properties of the agents themselves (see Archer, 1995, p. 157).

Insert Figure 1. Diachronic and synchronic emergence of agency in organizational groups.

These types of multilevel relations appear in other collective constructs, such as team creativity, which is assumed to depend on the organizational context, the heterogeneity of team members and the team's interaction processes (Drazin et al., 1999; Gupta, Tesluk, \& Taylor, 2007; West, 2002). Corporate entrepreneurship is seen as the result of the 'interlocking entrepreneurial activities of multiple participants' at different organizational levels (Burgelman, 1983, p. 1349). Whereas studies of agency also identify the importance of coordinated action (e.g. Garud \& Karnøe, 2003), and provide knowledge about group processes (e.g. Dorado, 2005; McCarthy \& Wolfson, 1996; Reay, GoldenBiddle, \& Germann, 2006), there is little knowledge regarding which properties of individuals are important in the emergence of collective agency or how groups are internally structured. In the following, we analyse the emergence of agency in temporary development groups in professional service organizations, focusing on phases T1-T3 in Figure 1. This meso-level context provides insights into how collective transformative agency emerges when organizational members, who typically interact in ordinary customer projects, form differently structured groups to develop their services. 


\section{Empirical Setting and Methods}

Service development activities in professional service firms (PSFs) offer interesting contexts for analysing transformative agency. Professional employees are often considered to have the best ability to reflect on the firm's objectives and knowledge bases on upcoming customer cases (Alvesson, 2004; Sundbo, 1997), and they can carry out service development without any central coordination, either collectively or as ‘individuals' hobbies' (Heusinkveld \& Benders, 2003), applying novel ideas directly to customer projects (Gallouj \& Weinstein, 1997). Thus, transformative agency is likely to be dispersed throughout the organization, depending on institutional and organizational contexts and members.

We studied different types of service development practices in five PSFs to identify and explain how transformative agency emerged and differed in these contexts. A multiple case study provides the means to explore variations in how contexts condition agency, which helps to identify causal mechanisms and develop theoretical ideas (Ackroyd \& Karlsson, 2014; Stake, 2005). We chose organizations that provide project-based business services in different professional fields, each with a reputation for innovation in its field. The organizations comprise units focused on specific service areas. We selected cases that represent variations in the contexts (the field and the maturity of the service areas) and transformative projects (ranging from organization-wide to local development processes). We focused on three service areas in each organization, varying from rapidly developing to mature areas (see Table 1). We anticipated that these differences might be important regarding transformative agency, as development opportunities are more frequent in rapidly developing areas than in mature areas. 
Table 1 shows the chosen organizations and service areas. DesCo is an architecture firm that has actively developed its capabilities in selected service areas. AdCo provides marketing communications services in many mature service areas, but new channels, such as digital marketing, have provided some development opportunities. AcCo's dominant service area is traditional accounting. However, we focused on its rapidly expanding advisory service areas. EngCo's core expertise is in mature building design services, but it also includes a rapidly developing property management consultancy area. Lastly, BuildCo's core expertise is in the mature construction consultancy area, but it has also expanded into two new areas: infrastructure consultancy and property development.

Insert Table 1. Case organizations and studied service areas.

\section{Data collection}

Because transformative agency as human potential is not directly observable, we collected interview data about transformative actions and the enablers and expectations related to these actions. These data provide different clues about the agentic potential of organizational members and the contextual conditioning of this potential (Ackroyd \& Karlsson, 2014). The primary data comprises fifty-three interviews with individuals occupying different organizational positions and having different views on service development. We interviewed senior managers and approximately three individuals from each service area, including a professional employee, a project manager/team leader and a unit manager. The interviews were semi-structured and lasted between one and a half to two hours. 
We approached the topics from multiple perspectives, and compared findings within and between interviews to overcome limitations in interviewees' perspectives and discursive knowledge (Fleetwood, 2005). The interviewees provided data concerning their own and others' roles in service development. They were asked to describe their own backgrounds, work roles and work practices, typical service development practices (with examples and deviations), and roles and role expectations in service development. Documentation of the firms' structures, services and strategies was collected to better understand the context. We discussed the preliminary findings with each firm and collaborated with them for several years, which strengthened our contextual understanding.

\section{Data analysis}

We conducted content analyses that iterated with the development of the theoretical framework (Dubois \& Gadde, 2002; Reed, 2005). The analysis involved phases, which Vincent and Wapshott (2014) described as configurational and normative analysis (i.e. describing what different people do and norms underlying their actions), field analysis (i.e. assessing how contextual features help explain the identified matters) and institutional explanation (i.e. revealing the causes of conditioning mechanisms). The first author was responsible for the analysis, while the second author carried out small-scale analyses to verify the categories.

The first part of the analysis involved configurational analysis, focusing on how different actors were involved in service development at time T2-T3. The actors' involvement in these activities indicated that they had some transformative agency. This analysis was supported by normative analysis of the role expectations related to these actions. We analysed descriptions of roles and development practices, summarizing these data in 
position-based matrices that indicated who was typically engaged in service development activities. During this process, we identified several types of development practices with different participants and goals. This served as the basis for identifying agentic groups, which we defined as (temporary) groups of organizational members who interacted to pursue a common service development goal. Many groups were temporary and loosely integrated, whereas others were continuous but had changing membership. Nevertheless, because they combined the members' contributions to create a particular output, we considered them entities with their own causal influence in their service areas (ElderVass, 2005).

We categorized these groups into different types based on the participants and the groups' internal structures. This supported analysing the synchronic emergence of collective transformative agency by helping to distinguish between the properties of the members and their relations (Elder-Vass, 2005, 2010). While describing and bracketing the members' tasks into generalized categories, we noticed that the structures of the groups differed in terms of who was involved in (a) exploring and evaluating ideas and opportunities and/or (b) mobilizing changes. We considered these differences as manifesting the participants' transformative agency within the groups, with the former manifesting future-oriented reflexive tendencies (Archer, 2003; Delbridge \& Edwards, 2013), and the latter manifesting bargaining power (Archer, 1995).

Table 2 shows the identified group types and their practices in different contexts. These group types in each organization were treated as the empirical cases in comparative analyses. Some cases, such as Case 10, represent similar groups identified in several units at AcCo. However, others, such as Case 7, describe a single development practice. Many 
interviewees were involved in several groups. We did not interview all group members, but relied on one or several group members and other interviewees who mentioned the group (see the last column in Table 2). We believe that these informants described the group structures at a level sufficient for our purposes (Kozlowski \& Klein, 2000). By relying on several informants and by identifying several examples of each group type, the data provide a good basis for comparisons.

Insert Table 2. The identified development group types.

The second phase of the analysis focused on explaining the principles underlying transformative agency. This continued the configurational analysis; we explored why the actors were involved in the way they were by comparing their agentic actions and resources within and across cases. We used the interviewees' descriptions of the assets and qualities needed in specific actions as cues in forming working propositions, which were then tested across interviews to ascertain whether patterns existed (Leca \& Naccache, 2006). We used this replication tactic iteratively in within- and cross-case analyses to specify the propositions and contexts in which they applied (Miles \& Huberman, 1994, p. 174). This analysis suggested how resources were connected with agentic actions in the observed groups, and therefore, provided a partial explanation for the diachronic emergence of agency.

Finally, we carried out field analysis to understand how the case contexts conditioned the diachronic emergence of transformative agency via the distribution of resources. Via cross-case comparisons, we identified connections between resource distributions and the 
maturity of the service area and leadership style in the service area. The interviewees also described tactics for pushing their ideas forward if their resources were not acknowledged in the service area. These insights led us to suggest how micro- and macro-level developments conditioned transformative agency via their influence on resource distributions. Taken together, the analysis provides an empirical explanation for and refinement of the relations suggested in Figure 1.

\section{Findings}

We begin this section by describing service development groups and their transformative actions at time T2-T3 to provide insights into synchronic emergence of agency in the studied groups. We then describe resources related to transformative actions and resource distributions in the studied service areas to yield evidence about the conditioning influence of the context (diachronic emergence of agency).

\section{Synchronic emergence of agency: Group members and group structures}

Service development activities were dispersed throughout the studied organizations. Some development groups spanned across and beyond current service areas, others were identified within the service areas and the rest operated within customer projects. Though all of the identified groups had some effects on their service areas, which indicated their transformative agency, their participants and internal structures differed in terms of how two types of transformative actions were dispersed among individuals. The first type, exploring and evaluating ideas and opportunities for service development, can be seen as reflexive deliberations oriented towards future possibilities (Delbridge \& Edwards, 2013). These activities involved analysing the present situation in the service area, and 
then relating new opportunities and resources to this situation to come up with useful ideas for future development. These activities thus resembled autonomous and metareflexive deliberations (Archer, 2003). The second type of transformative action, mobilising the change, included selling ideas to others, persuading others to use their resources for developing the idea, investing one's own time and expertise in development and convincing customers to use the developed concepts (Dorado, 2005; Howell \& Higgins, 1990). Therefore, we considered these actions exercises of bargaining power. Based on the centralization or decentralization of the two activities, we identified five types of groups. These types are summarized in Table 3 and discussed below.

Insert Table 3. The distribution of activities in the five types of groups.

Strategic development groups spanned organizations. They were intended to realize strategic objectives that influenced many service areas or required new expertise (Cases 1-5). Both exploring and evaluating ideas and mobilizing change were centralized to senior managers. With the help of unit managers, they defined goals, explored new ideas and mobilized resources for development. They also invited employees with relevant expertise to implement the actual changes within the given frameworks. For example, a strategic development group at AdCo (Case 2) aimed to improve capabilities in new marketing channels and develop new consultancy services and multichannel solutions. The managers developed preliminary service concepts, and ordinary customer project groups realized these concepts when opportunities arose in customer cases. A senior manager explained the centralized structure: 
Management should have a clear understanding of the firm's vision, where it is heading and what is required from different organizational levels.... What should be done and which skills are to be developed. ... It requires strong managerial vision, because if we lack vision, ideas will surely come from every level, but we cannot lead a firm like this by voting for what feels good on a given day.

Though strategic development groups were influential at the organizational level, we identified several types of groups within the existing service areas. Centralised development groups consisted of individuals who shared an intrinsic or extrinsic interest in developing their unit's business (Cases 6-8). Their structures were similar to those of the strategic development groups: one or a few dominant actors decided on the courses of action, while others were seen primarily as objects of and resources in the change. A group developing DesCo's sports venue concept (Case 6) is a typical example. Having created the unit's service concept, the unit manager took responsibility for developing it further. He considered himself to be the most experienced person in the area, and reflected his ideas with senior managers. His subordinates were primarily responsible for applying the ideas in the operative customer work. He discussed new ideas with experienced employees, but they were not expected to act autonomously, in part because the unit manager viewed strong experience as a prerequisite for service development:

In the development of innovations in our business, the fact is that anyone can come up with crazy ideas, but certain [useful] ideas can only be developed through experience.

The interviewed employees thought that they could get their ideas across if they did not give up too easily. This indicates that they, too, could engage in future-oriented reflexive considerations, but had limited bargaining power for direct action. As one stated, 'I have a feeling that I could do better had I more possibilities to influence'. 
In managed development groups, everyone was free to suggest ideas and opportunities, but only one or a few actors, such as unit managers, could mobilise change: they evaluated ideas and assigned development tasks to members (Cases 9-12). For example, at AcCo, every employee was encouraged to participate in service development (Cases 9 and 10), but senior members decided which ideas were developed further. A senior manager explained:

You have to have a fairly good level of competence. You need to know the routines since idea generation often requires challenging the taken-for-granted thoughts, which requires knowing those thoughts and the underlying principles. Therefore, ideas typically derive from those with seniority. It does not mean that everyone is not expected or allowed to participate.

In collective development groups, both exploring and evaluating ideas and mobilizing change were decentralized, and carried out collectively by the group members (Cases 1315). For example, DesCo's workplace design service drew on the unit members' idiosyncratic expertise. Therefore, everyone's insights were equally important when updating the service (Case 13). The unit manager referred to his subordinates as 'a group of experts' that he facilitated, describing their democratic practices as follows:

It is essential that everyone is involved; everyone's opinion is requested, and everyone can present ideas.

In the fifth type of group, the dispersed development group, employees developed their professional domains and created novel solutions to customer problems without much consideration for replicability in future assignments (Cases 16-19). Due to lack of coordination, these collectivities resembled primary agents (Archer, 1995): Both activity 
types were decentralized and carried out autonomously in customer projects. Eventually, these improvisations accumulated as individuals learned from each other in changing project teams. An employee at BuildCo (Case 19) explained their autonomy as follows:

An outsider would face difficulties in telling us how to carry out the work if s/he had not done the work even for a day. They [new solutions] are born in our work community, and it is not constricted in any way; we do not have any guidelines suggesting that we should first present the ideas to someone at a higher organizational level.

These findings indicate that the members' future-oriented reflexive potentials and bargaining powers differed within a group, and that these differences were larger in the first two group types, in which supervisors could inspire/command others to pursue their agendas. Subordinates' bargaining power was weaker, and their interests in futureoriented action were in some cases more extrinsic than intrinsic (see e.g. Elder-Vass, 2015). In these groups, the lack of bargaining power led some of the future-oriented interviewees to withdraw, as they had difficulties getting their ideas across. In the latter three group types, the members were more equal in their agentic properties.

These findings demonstrate how individuals' transformative agency emerged synchronically from relations between two agentic properties, reflexive tendencies and bargaining power, causing the observed differences between their agentic actions. Furthermore, we suggest that collective transformative agency emerged synchronically from combinations of the individuals' properties: in many groups, different individuals were needed to gain a broad perspective on future possibilities and mobilize necessary actors and resources, and the dispersion of these properties among organizational members influenced the group structures. 


\section{Diachronic emergence of agency: The conditioning influence of resources}

Next, we describe how contexts conditioned transformative agency diachronically via resource distributions. We first analysed the resources (assets and qualities), which were connected to the two types of transformative actions, and then compared resource distributions and group structures in the studied service areas.

Table 4 summarizes the findings concerning links between transformative actions and resources in different groups. These findings suggest that the first activity type, exploring and evaluating ideas and opportunities, was carried out by those who had—or who were perceived to have-relevant professional expertise, practical experience in the field and knowledge of strategy and resources. These resources were supported by access to professional and firm-specific networks and customer contacts. We anticipated that they stimulated future-oriented reflexive deliberations. For example, the senior managers could identify and evaluate cross-organizational opportunities in strategic groups because of their expertise, contact networks and broad knowledge of the firm. A project manager at DesCo discussed managers' roles in strategic groups (Case 1) as follows:

We don't speak about those things [new service opportunities, new customers] within units because we trust the abilities of the executive team. I think this is a good thing. Sure we could spend our time on idea generation, but since we don't have enough knowledge about important factors to make decisions, it is a waste of time.

Whereas these activities were centralized in the first two group types, professionals were considered capable of exploring and evaluating situated service development opportunities in the three latter group types on the basis of their expertise and ongoing engagement with customers. A creative designer at AdCo (Case 17) explains: 
To be able to perceive issues quite broadly, you should be able to do that... For example, you should be able to imagine how grocery stores will develop in Finland in the next five years. You should be able to come up with some ideas. If you cannot, you might be in the wrong business [laughing].

Insert Table 4. The distribution of activities and resources in different types of groups.

The second activity type, mobilizing change, was connected to authority, autonomy and contacts with customers and other stakeholders within the industry. These actions were centralized in the first three group types, carried out collectively in the fourth, and decentralized among autonomous members in the fifth. In the first three group types, managers' formal authority enabled mobilizing change. The CEO at DesCo described these connections as follows (Case 1):

I am often the generative power that makes things move and that ensures that things get done because I am... I have the advantage that I am the one sitting on the pile of money, which means that I can make decisions just like that.

Autonomy of the service areas enabled centralized, collective and managed groups within units to mobilize change in their service areas independent of senior managers. The unit manager at BuildCo explained his autonomy as follows (Case 8b):

Our unit is so different that what others do here does not influence us very much. We have a team of four, and we have such a broad mandate to act that we do what we consider is best. 
Similarly, the professionals' autonomy in their work enabled small-scale improvisations in dispersed groups when individual employees had the necessary knowledge and contacts. However, to implement new concepts, customer contacts were essential in all cases. An assistant manager at AcCo explained why (Case 10):

The validity, or value, of our innovation activities is, in the end, determined when we identify a concrete case where we can test the idea and see the reactions of the tax administrators — or, actually, our customer tests whether the concept works as planned. In this way, we can evaluate whether the idea works or not.

We assume that autonomy, authority and contacts strengthened individuals' bargaining power within the organization, which enabled them to mobilize change. Furthermore, different resources enabled them to persuade different actors. For example, the unit manager's autonomy in the centralized group developing DesCo's sports area (Case 6) enabled him to make independent decisions, and his customer contacts and authority over subordinates enabled him to implement the ideas.

\section{Resource distributions: Field-level conditions and previous interactions}

The resources described above were distributed evenly in some service areas, while in others, they tended to accumulate towards individuals occupying higher positions, which influenced unit members' agency and the structures of agentic groups. Even though some interviewees managed to use external resources in their transformative actions, many resources were linked to individuals' work, and the transformative agency of individuals with relevant positions was acknowledged, or even expected (Battilana, 2006; Sørensen, Sundbo, \& Mattsson, 2013). We analysed these resource distributions and underlying explanations to better understand the diachronic emergence of transformative agency. 
These analyses suggest that resource distributions at the time of the study were influenced by both developments in the professional fields and interactions among organizational members.

First, the resource distributions depended on the maturity of the service area and the underlying professional field. Table 5 compares the size and maturity of the service areas and the types of agentic groups. In areas with low maturity, resources and transformative actions tended to be more evenly distributed among members, and all types of agentic groups were identified. Managed and collective groups were much more common in rapidly developing areas than in mature areas. We estimate that divergent and changing situations accumulated resources that enabled the members to be broadly involved both in reflexive deliberations and the mobilization of change. Routinized work practices in mature service areas provided fewer resources and development opportunities, and centralized, managed or collective groups were less common. Service development often relied only on small-scale improvisation in dispersed groups or on organization-wide strategic development groups. Even though some formal opportunities for development were organized, such as in Case 12, individuals showed no interest in pursuing changes due to tight schedules and a lack of resources.

Insert Table 5. Group types and the maturity of service areas

Second, the findings suggest that previous interactions between organizational members had influenced resource distributions. Leadership style seemed to play an important role. Consider, for example, the differences between workplace design (Case 13) and sports 
venue design areas at DesCo (Case 6). In both areas, development opportunities existed, but group structures were strikingly different. In workplace design, the customer projects were diverse, and the unit manager engaged the professionals in project planning. The employees accumulated a variety of experiences and broad expertise, which likely motivated and enabled them to develop their services, leading to the collective development group format. The sports area also included development opportunities, but broader expertise and contacts accumulated to the ambitious unit manager. Ordinary employees focused on repetitive design tasks, which created deep but focused knowledge. Thus, a centralized development group format was established. Had the unit manager engaged the members in development, they would have had better opportunities to develop their resources. A senior manager explained the central role of the unit manager as follows:

It is a question of personality, of who makes things happen. [The manager of the sports unit] is terribly active; he has a burning desire to advance his projects, and he often uses us as mirrors when validating his thoughts. In [other units], it is the other way around.

Furthermore, some interviewees without legitimate positions managed to establish their agency and shape group structures by incorporating and legitimizing new resources, such as expertise and contacts from previous work, and combining them with resources already acknowledged within the organization (Howard-Grenville, 2007; Leca \& Naccache, 2006). For example, a team leader in EngCo's consultancy area wanted to develop an ITbased service for his local customers (Case 11), but employees did not typically have IT skills, and an IT manager was supposed to control software development. Defying norms, he managed to develop the service with his team, using his $R \& D$ skills from previous 
work, autonomy, authority and customer contacts. He informed his supervisor after implementing the service locally, and his competences were acknowledged afterward.

At BuildCo, outsiders created two new service areas by legitimizing their external resources in the firm's context. The creator of the property development area (Case 8b) had earlier worked at BuildCo and thereafter in several other positions in the industry. His diverse experience helped him identify new opportunities, and knowing BuildCo's context, he was able to evaluate the compatibility of the idea to the firm and convince the CEO:

Yes, I proposed to the CEO that perhaps we should merge our competences, and it did not take long to come true. I knew such activities would fit into this particular firm, and then I developed the idea and noticed that I'd be ready to do it. This is how it went.

He was then given free rein to establish a new service area, hire new experts and sell the first projects, which proved the value of his resources in practice.

These illustrations show how previous morphogenetic cycles influenced the transformative agency of individuals and groups by shaping the distribution of resources among organizational members at time T1-T2. Agency was shaped by both resources linked to organizational positions and resources derived from other structures. In the above examples (Cases 8 and 11), experiences from several contexts likely inspired future-oriented reflexive deliberations, and enabled the team and unit managers to identify new resources and establish their bargaining power. Subsequent changes in their positions generated additional resources that further stimulated their reflexive deliberations and strengthened their bargaining power. Whereas our study intended to analytically separate different phases and entities in the emergence of transformative 
agency, these examples show that the diachronic and synchronic emergence of agency are intensively intertwined.

\section{Discussion}

This paper aimed to clarify the emergence of transformative agency at the individual and collective levels in professional service organizations. Here, we use the empirical findings from the examined temporary development groups to elaborate on the theoretical framework suggested in Figure 1. Then, we evaluate the contributions and implications of the study.

Diachronic and synchronic emergence of transformative agency in service development

Figure 1 suggested how analyses of diachronic and synchronic emergence can clarify the relations between context and transformative agency, as well as between transformative agency at the individual and collective levels. Figure 2 summarizes the empirical findings, paying attention to how context influences individual properties from which individuals' transformative agency emerge, and how group-level transformative agency emerges from the situated combination of these properties.

First, time T1-T2 characterizes how the previous morphogenetic cycles diachronically shaped the reflexive tendencies and bargaining power of individuals in a given service area. In the studied organizations, the macro-level morphogenetic/static developments led to a situation in which some service areas were mature while others provided development opportunities. Micro-level interactions between unit leaders and unit members either strengthened hierarchical division of work or empowered unit members. 
We assume that the interplay between these processes, along with the members' personal histories, influenced organizational members' resources and, subsequently, their agentic properties. However, the tendency to engage in future-oriented reflexive deliberations was shaped by both the individuals' personal histories and current positions, and bargaining power was more explicitly connected to resources derived from present organizational positions, such as authority, autonomy and contacts.

Second, we suggest that individuals' transformative agency emerged synchronically from the relations between reflexivity and bargaining power. The findings suggest that reflexivity and bargaining power influenced one another in the emergence of agency: Some actors, such as the new unit managers at BuildCo, built their bargaining power by reflexively relating new resources to their service areas (Daudigeos, 2013), and bargaining power provided access to resources, which inspired future-oriented reflexive deliberations. On the other hand, some interviewees who lacked bargaining power oriented themselves towards the present action and forgot their ideas (Dorado, 2013). Whereas either property alone enabled some transformative contributions, both were needed to pursue and achieve a transformative effect.

Third, we assume that collective transformative agency emerged synchronically from the relationships between group members, as the organizational members formed differently structured temporary groups to pursue a particular development need at time T2-T3. The members contributed to group processes with different actions, and group interactions did not activate all of the members' agentic potential; some properties, such as reflexive abilities, were suffocated by power relations among group members (Mutch, 2010b). This shows that whereas transformative agency could exist without being exercised, the 
actualization of agentic action at time T2-T3 depended on situational opportunities (identification of needs or opportunities for service development) and the relations between organizational members, including the manner in which they evaluated each other's agentic potential (Archer, 1995).

Insert Figure 2. Emergence of transformative agency in the studied cases.

Our empirical analysis focused on the formation and internal qualities of agentic groups at times $\mathrm{T} 1-\mathrm{T} 3$, rather than on their interactions with other groups and the consequent structural change at T3-T4. The morphogenetic model suggests that group interactions at time T2-T3 can lead to either local or organization-wide changes at time T3-T4. These changes can diachronically influence resource distributions at individual and group levels, conditioning the emergence of individual-level transformative agency and the regrouping of agents in the following morphogenetic cycles.

\section{Contribution of the study and future research needs}

Separating transformative agency from agentic action and analysing relations between properties at different levels provides multilevel and contextual explanations of agentic action. This conceptualization contributes to studies of transformative agency in organizations in two ways. First, it advances the conceptualization of individual-level transformative agency as a durable but relative potential; it is durable as it changes diachronically in conjunction with structural change (Archer, 1995), but it is also relative to the tasks at hand and to the agency of other actors in the organizational context (Burkitt, 2016). We anticipate that the two properties underlying agency-reflexivity and 
bargaining power-differ in terms of durability and relativity. Whereas bargaining power is more explicitly tied to the focal structure and actors embedded in this structure, reflexive tendencies are more durable and less explicitly conditioned by it. Nevertheless, in line with Mutch (2004), we suggest that reflexivity is also influenced by resources; one needs to know the context in order to identify opportunities for change (e.g., Reay et al., 2006). In order to understand individuals' roles in organizational change, more research is needed to understand how these properties emerge and interact to create individuals' transformative agency in different organisational contexts.

Second, the study brings depth to conceptualizations of collective transformative agency by analysing the synchronic emergence of collective agency from group members' properties and relations (Elder-Vass, 2005). While there is growing interest in transformative agency at collective levels in organizational and institutional studies (Bridwell-Mitchell, 2016; Hargadon \& Bechky, 2006; Wijen \& Ansari, 2007), the internal group structures and processes that give rise to group-level agentic potential are seldom addressed. Our study shows the importance of these internal properties for the emergence and actualization of collective transformative agency. The study focused on professional service firms in which the professionals who focused on service provision in their daily work could occasionally pursue change by organizing in a manner that activated and combined their individual properties in a new way. This suggests that group members' individual properties need to be separated from the more temporary, synchronic emergence of their collective-reproductive or transformative-agency in such ambidextrous organizational settings. 
The study has some limitations that invite further research on collective transformative agency. First, there is a need to elaborate on the modes of reflexivity in groups with indepth empirical case studies. Whereas resource mobilization in groups has been discussed in institutional studies (Battilana, Leca, \& Boxenbaum, 2009; Dorado, 2013) and social movement studies (Desa, 2012; McCarthy \& Wolfson, 1996), little is known about how individuals' different reflexive properties contribute to collective agency. The reflexive conversations we studied resembled autonomous and meta-reflexive conversations in their orientation towards the future, but were not carried out as autonomously as the original model suggests (Archer, 2012). Even though the dominant persons in the centralized and strategic groups resembled autonomous reflexives (Mutch, 2007), collective groups discussed ideas together, thus resembling groups of 'collective metareflexives' (Archer \& Donati, 2015) or 'communicative reflexives' (Archer, 2003, 2012), but with transformative interest. Furthermore, it is also possible that those not participating in exploring and evaluating ideas contributed to the groups' agency with their reflexivity, even though our data provided limited information about these influences. There is a need to separate the manner in which reflexive conversations are carried out from their content (Porpora \& Shumar, 2010) and to analyse how different modes of reflexivity combine to form collective transformative agency.

Second, longitudinal studies are needed to analyse the diachronic emergence of collective transformative agency over time when contexts change. In our study, the maturation of a service area tended to lead to more polarized resource distributions in which ordinary employees' transformative agency was weaker and centralized and dispersed groups were common. In rapidly developing areas, resource distributions were more equal, and coordinated or managed groups emerged. Though individuals with external resources 
could sometimes change these tendencies, their agentic potential was nevertheless relative to the potential of others (see also Burkitt, 2016). More research is needed on the reciprocal influence of individual and collective transformative agency over time as resource distributions change. Though this study focused on temporary development groups, the interplay between individual and collective agency may be more complex in continuous groups. Furthermore, we focused on the internal qualities of development groups, rather than on inter-group interactions in morphogenetic processes. Longitudinal studies could extend the multilevel analysis to explore the morphogenesis of agency over time in conjunction with inter-group interactions and organizational and institutional change.

\section{Conclusions}

This study elaborates the view of agency as a relational and emergent potential of individuals and groups (Archer, 1995; Emirbayer, 1997; Mutch et al., 2006). The findings deepen our understanding of the emergence of transformative agency using the critical realist models of Archer (1995) and Elder-Vass (2005). The findings suggest that we should pay more attention to the internal dynamics of agentic groups to understand the emergence and elaboration of transformative agency in organizational change. In conclusion, we believe that critical realist approaches have unused potential to explicate the relations between social entities in organizational change. While the morphogenetic model has been used to address institutional change, our study indicates that it could be more extensively applied at lower levels of analysis to explain a variety of organizational situations, whereby the interplay between agency and context may lead to unexpected outcomes at various levels and layers of organizational reality. 


\section{Author biographies}

Tiina Tuominen is an affiliated postdoctoral researcher at the Aalto University School of Science, Department of Industrial Engineering and Management. She was also a research associate at the Hanken School of Economics, Department of Marketing, during 20142016. Her research interests focus on individual and collective aspects of innovation and change.

Mikko Lehtonen, M.Sc.(Tech.), M.Sc.(Econ.) is a management consultant at InnotiimiICG and a doctoral candidate at Aalto University School of Science, Department of Industrial Engineering and Management. His research interests are critical perspectives on service development, project and programme management, organizational changes, control and power.

\section{Acknowledgements}

We would like to thank the three anonymous referees and senior editor Bernard Leca for their critical and constructive feedback. We are also grateful for the comments on the tentative model from the participants in the reflexivity track at the $8^{\text {th }}$ International Conference on Critical Management Studies in 2013.

\section{Funding}

This work has been supported by the Finnish Work Environment Fund (grant numbers 113167, 115374) and the Evald and Hilda Nissi Foundation. The empirical data was collected in a project funded by the case firms and the Finnish Funding Agency for Innovation. 


\section{References}

Ackroyd, S., \& Karlsson, J. C. (2014). Critical realism, research techniques, and research designs. In P. Edwards, J. O’Mahoney, \& S. Vincent (Eds.), Studying organizations using critical realism: a practical guide (pp. 21-45). New York: Oxford University Press.

Alvesson, M. (2004). Knowledge work and knowledge-intensive firms. New York: Oxford University Press.

Archer, M. S. (1995). Realist social theory: the morphogenetic approach. Cambridge, UK: Cambridge University Press.

Archer, M. S. (2000). Being human: The problem of agency. West Nyack, NY: Cambridge University Press.

Archer, M. S. (2003). Structure, agency and the internal conversation. Cambridge, UK: Cambridge University Press.

Archer, M. S. (2012). The reflexive imperative in late modernity. New York: Cambridge University Press.

Archer, M. S. \& Donati, P. (2015). The plural subject versus the relational subject. In P. Donati \& M. S. Archer (Eds.), The relational subject (pp. 33-76). Cambridge, UK: Cambridge University Press.

Battilana, J. (2006). Agency and institutions: The enabling role of individuals' social position. Organization, 13(5), 653-676. 
Battilana, J., \& D'Aunno, T. (2009). Institutional work and the paradox of embedded agency. In T. B. Lawrence, R. Suddaby, \& B. Leca (Eds.), Institutional work: actors and agency in institutional studies of organizations (pp. 31-58). Cambridge, UK: Cambridge University Press.

Battilana, J., Leca, B., \& Boxenbaum, E. (2009). 2 how actors change institutions: towards a theory of institutional entrepreneurship. The academy of management annals, 3(1), 65-107.

Bridwell-Mitchell, E. (2016). Collaborative institutional agency: How peer learning in communities of practice enables and inhibits micro-institutional change. Organization Studies, 37(2), 161-192.

Burgelman, R. A. (1983). Corporate entrepreneurship and strategic management: Insights from a process study. Management science, 29(12), 1349-1364.

Burkitt, I. (2016). Relational agency: Relational sociology, agency and interaction. European Journal of Social Theory, 19(6), 322-339.

Caldwell, R. (2005). Things fall apart? Discourses on agency and change in organizations. Human Relations, 58(1), 83-114.

Daudigeos, T. (2013). In their profession's service: How staff professionals exert influence in their organization. Journal of Management Studies, 50(5), 722-749.

Delbridge, R., \& Edwards, T. (2013). Inhabiting institutions: Critical realist refinements to understanding institutional complexity and change. Organization Studies, 34(7), 927-947. 
Desa, G. (2012). Resource mobilization in international social entrepreneurship: Bricolage as a mechanism of institutional transformation. Entrepreneurship Theory and Practice, 36(4), 727-751.

Dorado, S. (2005). Institutional entrepreneurship, partaking, and convening. Organization Studies, 26(3), 385-414.

Dorado, S. (2013). Small groups as context for institutional entrepreneurship: An exploration of the emergence of commercial microfinance in Bolivia. Organization Studies, 34(4), 533-557.

Drazin, R., Glynn, M. A., \& Kazanjian, R. K. (1999). Multilevel theorizing about creativity in organizations: A sensemaking perspective. The Academy of Management Review, 24(2), 286-307.

Dubois, A., \& Gadde, L.-E. (2002). Systematic combining: an abductive approach to case research. Journal of Business Research, 55(7), 553-560.

Edwards, T., \& Meliou, E. (2015). Explaining leadership in family firms: Reflexivity, social conditioning and institutional complexity. Human Relations, 68(8), 12711289.

Elder-Vass, D. (2005). Emergence and the realist account of cause. Journal of Critical Realism, 4(2), 315-338.

Elder-Vass, D. (2007). Social structure and social relations. Journal for the Theory of Social Behaviour, 37(4), 463-477. 
Elder-Vass, D. (2010). The causal power of social structures: Emergence, structure and agency. Cambridge, UK: Cambridge University Press.

Elder-Vass, D. (2015). Collective intentionality and causal powers. Journal of Social Ontology, 1(2), 251-269.

Emirbayer, M. (1997). Manifesto for a relational sociology 1. American journal of sociology, 103(2), 281-317.

Emirbayer, M., \& Mische, A. (1998). What is agency? American Journal of Sociology, 103(4), 962-1023.

Feldman, M. S., \& Orlikowski, W. J. (2011). Theorizing practice and practicing theory. Organization Science, 22(5), 1240-1253.

Fleetwood, S. (2005). Ontology in organization and management studies: A critical realist perspective. Organization, 12(2), 197-222.

Gallouj, F., \& Weinstein, O. (1997). Innovation in services. Research Policy, 26(4-5), $537-556$.

Garud, R., Hardy, C., \& Maguire, S. (2007). Institutional entrepreneurship as embedded agency: An introduction to the special issue. Organization Studies, 28(7), 957969.

Garud, R., \& Karnøe, P. (2003). Bricolage versus breakthrough: distributed and embedded agency in technology entrepreneurship. Research Policy, 32(2), 277300. 
Giddens, A. (1984). The constitution of society: outline of the theory of structuration. Berkeley: University of California Press.

Gupta, A. K., Tesluk, P. E., \& Taylor, M. S. (2007). Innovation at and across multiple levels of analysis. Organization Science, 18(6), 885-897.

Hargadon, A. B., \& Bechky, B. A. (2006). When collections of creatives become creative collectives: A field study of problem solving at work. Organization Science, 17(4), 484-500.

Hargrave, T. J., \& Van de Ven, A. H. (2006). A collective action model of institutional innovation. Academy of Management Review, 31(4), 864-888.

Herepath, A. (2014). In the loop: A realist approach to structure and agency in the practice of strategy. Organization Studies, 35(6), 857-879.

Heusinkveld, S., \& Benders, J. (2003). Between professional dedication and corporate design: Exploring forms of new concept development in consultancies. International Studies of Management \& Organization, 32(4), 104-122.

Howard-Grenville, J. A. (2005). The persistence of flexible organizational routines: The role of agency and organizational context. Organization Science, 16(6), 618-636.

Howard-Grenville, J. A. (2007). Developing issue-selling effectiveness over time: Issue selling as resourcing. Organization Science, 18(4), 560-577.

Howell, J. M., \& Higgins, C. A. (1990). Champions of technological innovation. Administrative science quarterly, 317-341. 
Kozlowski, S. W., \& Klein, K. J. (2000). A multilevel approach to theory and research in organizations: Contextual, temporal, and emergent processes. In K. J. Klein \& S. W. Kozlowski (Eds.), Multi-level theory, research, and methods in organizations (pp. 3-90). San Francisco, CA: Jossey-Bass.

Lawrence, T. B., \& Suddaby, R. (2006). Institutions and institutional work. In S. R. Clegg, C. Hardy, T. B. Lawrence, \& W. R. Nord (Eds.), Handbook of organization studies (2nd Edition.). London, UK: Sage Publications.

Lawrence, T. B., Suddaby, R., \& Leca, B. (2011). Institutional work: Refocusing institutional studies of organization. Journal of Management Inquiry, 20(1), 5258.

Leca, B., \& Naccache, P. (2006). A critical realist approach to institutional entrepreneurship. Organization, 13(5), 627-651.

Levina, N., \& Orlikowski, W. J. (2009). Understanding shifting power relations within and across organizations: A critical genre analysis. Academy of Management Journal, 52(4), 672-703.

Llewellyn, S. (2007). Introducing the agents... Organization Studies, 28(2), 133-153.

McCarthy, J. D., \& Wolfson, M. (1996). Resource mobilization by local social movement organizations: Agency, strategy, and organization in the movement against drinking and driving. American Sociological Review, 61(6), 1070-1088.

McCarthy, J. D., \& Zald, M. N. (1977). Resource mobilization and social movements: A partial theory. American journal of sociology, 1212-1241. 
Miles, M. B., \& Huberman, A. M. (1994). Qualitative data analysis: an expanded sourcebook (2nd ed.). Thousand Oaks, CA: Sage Publications.

Morgeson, F. P., \& Hofmann, D. A. (1999). The structure and function of collective constructs: Implications for multilevel research and theory development. The Academy of Management Review, 24(2), 249-265.

Mrozowicki, A. (2010). The agency of the weak: ethos, reflexivity and life strategies of Polish workers after the end of state socialism. In M. S. Archer (Ed.), Conversations about reflexivity (pp. 167-186). New York: Routledge.

Mutch, A. (2004). Constraints on the internal conversation: Margaret Archer and the structural shaping of thought. Journal for the Theory of Social Behaviour, 34(4), $429-445$.

Mutch, A. (2007). Reflexivity and the institutional entrepreneur: A historical exploration. Organization Studies, 28(7), 1123-1140.

Mutch, A. (2010a). Technology, organization, and structure: A morphogenetic approach. Organization Science, 21(2), 507-520.

Mutch, A. (2010b). Organizational use of information and communication technology and its impacts on reflexivity. In M. S. Archer (Ed.), Conversations about reflexivity (pp. 243-258). New York: Routledge.

Mutch, A., Delbridge, R., \& Ventresca, M. (2006). Situating organizational action: The relational sociology of organizations. Organization, 13(5), 607-625. 
O’Mahoney, J., \& Vincent, S. (2014). Critical realism as an empirical project: A beginner's guide. In P. Edwards, J. O’Mahoney, \& S. Vincent (Eds.), Studying organizations using critical realism: A practical guide (pp. 1-20). New York: Oxford University Press.

Orlikowski, W. J. (1996). Improvising organizational transformation over time: A situated change perspective. Information Systems Research, 7(1), 63-92.

Porpora, D. A., \& Shumar, W. (2010). Self talk and self reflection: a view from the US. In M. S. Archer (Ed.), Conversations about reflexivity (pp. 206-220). New York: Routledge.

Reay, T., Golden-Biddle, K., \& Germann, K. (2006). Legitimizing a new role: Small wins and microprocesses of change. Academy of Management Journal, 49(5), 977-998.

Reed, M. (2005). Reflections on the "Realist Turn" in organization and management studies. The Journal of Management Studies, 42(8), 1621-1644.

Seidl, D., \& Whittington, R. (2014). Enlarging the strategy-as-practice research agenda: Towards taller and flatter ontologies. Organization Studies, 35(10), 1407-1421.

Smets, M., \& Jarzabkowski, P. (2013). Reconstructing institutional complexity in practice: A relational model of institutional work and complexity. Human Relations, 66(10), 1279-1309.

Sørensen, F., Sundbo, J., \& Mattsson, J. (2013). Organisational conditions for service encounter-based innovation. Research Policy, 42(8), 1446-1456. 
Stake, R. E. (2005). Qualitative case studies. Handbook of Qualitative Research (3rd ed., pp. 443-466). London, UK: Sage Publications.

Sundbo, J. (1997). Management of innovation in services. The Service Industries Journal, $17(3), 432-455$.

Vincent, S. (2008). A transmutation theory of inter-organizational exchange relations and networks: Applying critical realism to analysis of collective agency. Human Relations, 61(6), 875-899.

Vincent, S., \& Wapshott, R. (2014). Critical realism and the organizational case study: A guide to discovering institutional mechanisms. In P. Edwards, J. O’Mahoney, \& S. Vincent (Eds.), Studying organizations using critical realism: A practical guide (pp. 148-167). New York: Oxford University Press.

West, M. A. (2002). Sparkling fountains or stagnant ponds: An integrative model of creativity and innovation implementation in work groups. Applied psychology, 51(3), 355-387.

Whittington, R. (1992). Putting Giddens into action: Social systems and managerial agency. Journal of Management Studies, 29(6), 693-712.

Wijen, F., \& Ansari, S. (2007). Overcoming inaction through collective institutional entrepreneurship: Insights from regime theory. Organization Studies, 28(7), $1079-1100$. 


\section{Structural and cultural conditioning}

T1

Distribution of resources and interests and the pregrouping of agents

$\rightarrow$ Diachronic emergence of individual-level properties

$\rightarrow$ Synchronic emergence of individual-level agency from these

properties

Sociocultural action and group interaction

$\rightarrow$ Synchronic emergence and actualization of collective agency via interactions within and between groups

Structural elaboration and group elaboration

$\rightarrow$ Diachronic emergence of individual-level agency and regrouping of agents

Figure 1. Diachronic and synchronic emergence of agency in organizational groups.

Table 1. Case organisations and studied service areas. 


\begin{tabular}{|c|c|c|c|c|c|}
\hline $\begin{array}{l}\text { Firm } \\
\text { name* }\end{array}$ & $\begin{array}{l}\text { Professional } \\
\text { field }\end{array}$ & $\begin{array}{l}\text { Firm size } \\
\text { (person- } \\
\text { nel)** } \\
\end{array}$ & Studied service areas & $\begin{array}{l}\text { Personnel } \\
\text { in area }\end{array}$ & $\begin{array}{l}\text { Maturity of } \\
\text { area }\end{array}$ \\
\hline DesCo & $\begin{array}{l}\text { Architectural } \\
\text { design }\end{array}$ & 80 & $\begin{array}{l}\text { Sports venue design } \\
\text { Workplace design } \\
\text { Recreational venue design }\end{array}$ & $\begin{array}{l}13 \\
10 \\
20 \\
\end{array}$ & $\begin{array}{l}\text { Moderate } \\
\text { Low } \\
\text { Moderate } \\
\end{array}$ \\
\hline AdCo & $\begin{array}{l}\text { Marketing } \\
\text { communications }\end{array}$ & 55 & $\begin{array}{l}\text { Traditional marketing } \\
\text { Event marketing } \\
\text { Digital marketing } \\
\end{array}$ & $\begin{array}{l}30 \\
15 \\
8 \\
\end{array}$ & $\begin{array}{l}\text { High } \\
\text { Moderate } \\
\text { Moderate } \\
\end{array}$ \\
\hline AcCo & $\begin{array}{l}\text { Accounting and } \\
\text { advisory }\end{array}$ & 180 & $\begin{array}{l}\text { Tax advisory services } \\
\text { Financial advisory services } \\
\text { Risk advisory services }\end{array}$ & $\begin{array}{l}65 \\
55 \\
55 \\
\end{array}$ & $\begin{array}{l}\text { Low } \\
\text { Low } \\
\text { Low }\end{array}$ \\
\hline EngCo & $\begin{array}{l}\text { Engineering } \\
\text { design and } \\
\text { consultancy }\end{array}$ & 120 & $\begin{array}{l}\text { Electrical design } \\
\text { HVAC design } \\
\text { Property management } \\
\text { consulting } \\
\end{array}$ & $\begin{array}{l}40 \\
50 \\
30\end{array}$ & $\begin{array}{l}\text { High } \\
\text { High } \\
\text { Low }\end{array}$ \\
\hline BuildCo & $\begin{array}{l}\text { Construction } \\
\text { consultancy }\end{array}$ & 200 & $\begin{array}{l}\text { Construction consultancy } \\
\text { Infrastructure consultancy } \\
\text { Property development }\end{array}$ & $\begin{array}{l}80 \\
55 \\
4\end{array}$ & $\begin{array}{l}\text { High } \\
\text { Moderate } \\
\text { Low }\end{array}$ \\
\hline
\end{tabular}

* The names are pseudonyms. ** Excluding subsidiaries/sister companies abroad. 
Table 2. The identified development group types.

\begin{tabular}{|c|c|c|c|}
\hline & Contexts in each firm & Service development practices and goals & Informants \\
\hline \multicolumn{4}{|c|}{ 1. Strategic development groups } \\
\hline $\mathrm{C} 1$ & DesCo, firm-level & $\begin{array}{l}\text { Management-driven groups that aimed to improve market } \\
\text { position across units by developing new market areas and } \\
\text { service areas. }\end{array}$ & $5(+7)$ \\
\hline $\mathrm{C} 2$ & AdCo, firm-level & $\begin{array}{l}\text { Management-driven group that aimed to improve } \\
\text { competitiveness by, for example, developing new marketing } \\
\text { channels and consultancy services. }\end{array}$ & $6(+4)$ \\
\hline $\mathrm{C} 3$ & AdCo, firm-level & $\begin{array}{l}\text { Management-driven group that aimed to identify new } \\
\text { customer and offering types. Ideas were implemented within } \\
\text { service areas. }\end{array}$ & $7(+1)$ \\
\hline $\mathrm{C} 4$ & EngCo, firm-level & $\begin{array}{l}\text { Management-driven projects that implemented strategic } \\
\text { objectives, such as the development of new service areas. }\end{array}$ & $5(+2)$ \\
\hline $\mathrm{C} 5$ & BuildCo, firm-level & $\begin{array}{l}\text { An initiative of a new CEO to create new firm-wide strategy } \\
\text { and strategy-making practice in collaboration with unit } \\
\text { managers and members. }\end{array}$ & $4(+2)$ \\
\hline \multicolumn{4}{|c|}{ 2. Centralized development groups } \\
\hline C6 & $\begin{array}{l}\text { DesCo, sports venue } \\
\text { design }\end{array}$ & $\begin{array}{l}\text { Service development group driven by the unit manager. He } \\
\text { developed the unit's service concept, using employees as } \\
\text { resources. }\end{array}$ & $3(+1)$ \\
\hline $\mathrm{C} 7$ & $\begin{array}{l}\text { AcCo, tax advisory } \\
\text { services }\end{array}$ & $\begin{array}{l}\text { A new unit manager's effort to change the mindset towards a } \\
\text { customer-driven business logic. He developed the ideas with } \\
\text { teams, but controlled the process centrally. }\end{array}$ & 2 \\
\hline $\mathrm{C} 8$ & $\begin{array}{l}\text { BuildCo, infrastructure } \\
\text { consultancy (8a) and } \\
\text { property development } \\
\text { (8b) }\end{array}$ & $\begin{array}{l}\text { The creation of two new service areas by external persons. } \\
\text { They were then hired to develop the units autonomously, } \\
\text { supported by new recruits. }\end{array}$ & $2(+2)$ \\
\hline
\end{tabular}

\section{Managed development groups}

\begin{tabular}{llll}
\hline C9 & $\begin{array}{l}\text { AcCo, all three areas } \\
(9 \mathrm{a}-\mathrm{c})\end{array}$ & $\begin{array}{l}\text { Typical practice for developing advisory services at the unit } \\
\text { level. Everyone could participate, but decisions were made at } \\
\text { the unit level. }\end{array}$ & $8(+1)$ \\
\hline C10 & $\begin{array}{l}\text { AcCo, teams in all } \\
\text { three areas (10a-c) }\end{array}$ & $\begin{array}{l}\text { Typical practice for developing services within teams. } \\
\text { Everyone could participate, but senior team members made } \\
\text { decisions. }\end{array}$ & $8(+1)$ \\
\hline C11 & $\begin{array}{l}\text { EngCo, property } \\
\text { management consulting }\end{array}$ & $\begin{array}{l}\text { A team leader took autonomous action with his team to } \\
\text { develop services for their local customers. }\end{array}$ & $1(+1)$ \\
\hline C12 & $\begin{array}{l}\text { BuildCo, construction } \\
\text { consultancy }\end{array}$ & $\begin{array}{l}\text { Service development practice in a unit with limited } \\
\text { development resources. Everyone was encouraged to develop } \\
\text { services, but with the manager's permission. }\end{array}$ & $2(+1)$ \\
\hline 4. Collective development groups & $\begin{array}{l}\text { DesCo, workplace } \\
\text { design }\end{array}$ & $\begin{array}{l}\text { Large-scale collective development effort to improve the } \\
\text { unit's services. Every unit member participated } \\
\text { democratically. }\end{array}$ & $5(+1)$ \\
\hline C13 & $\begin{array}{l}\text { EngCo, some teams in } \\
\text { property management } \\
\text { consulting }\end{array}$ & $\begin{array}{l}\text { New service development practice in several teams that } \\
\text { considered development as a collective task. Everyone } \\
\text { participated equally. }\end{array}$ & $2(+1)$ \\
\hline C14 & $\begin{array}{l}\text { BuildCo, local team in } \\
\text { construction } \\
\text { consultancy }\end{array}$ & $\begin{array}{l}\text { Development process in which the team autonomously } \\
\text { developed their local services, discussing their ideas } \\
\text { collectively. }\end{array}$ & 1 \\
\hline C15 & &
\end{tabular}


Table 3. The distribution of activities in the five types of groups.

\begin{tabular}{|c|c|c|}
\hline & \multicolumn{2}{|c|}{ The distribution of transformative actions among group members } \\
\hline Group types & $\begin{array}{l}\text { Exploring and evaluating ideas } \\
\text { and opportunities }\end{array}$ & Mobilizing change \\
\hline $\begin{array}{l}\text { Strategic } \\
\text { groups } \\
\text { (Cases 1-5) }\end{array}$ & $\begin{array}{l}\text { Centralized: } \\
\text { Top managers act collectively; } \\
\text { minor contributions from others }\end{array}$ & $\begin{array}{l}\text { Centralized: } \\
\text { Top managers act collectively; } \\
\text { minor contributions from others }\end{array}$ \\
\hline $\begin{array}{l}\text { Centralized } \\
\text { groups } \\
\text { (Cases 6-8) }\end{array}$ & $\begin{array}{l}\text { Centralized: } \\
\text { Unit/team manager acts } \\
\text { autonomously; } \\
\text { minor contributions from others }\end{array}$ & $\begin{array}{l}\text { Centralized: } \\
\text { Unit/team manager acts autonomously; } \\
\text { minor contributions from others }\end{array}$ \\
\hline $\begin{array}{l}\text { Managed } \\
\text { groups } \\
\text { (Cases 9-12) }\end{array}$ & $\begin{array}{l}\text { Decentralized: } \\
\text { Unit/team members generate ideas } \\
\text { autonomously; ideas evaluated } \\
\text { centrally }\end{array}$ & $\begin{array}{l}\text { Centralized: } \\
\text { Unit/team manager acts autonomously; } \\
\text { minor contributions from others }\end{array}$ \\
\hline $\begin{array}{l}\text { Collective } \\
\text { groups } \\
(\text { Cases 13-15) }\end{array}$ & $\begin{array}{l}\text { Decentralized: } \\
\text { Unit/team members act collectively }\end{array}$ & $\begin{array}{l}\text { Decentralized: } \\
\text { Unit/team members act collectively }\end{array}$ \\
\hline $\begin{array}{l}\text { Dispersed } \\
\text { groups } \\
\text { (Cases 16-19) }\end{array}$ & $\begin{array}{l}\text { Decentralized: } \\
\text { Unit/team members act } \\
\text { autonomously }\end{array}$ & $\begin{array}{l}\text { Decentralized: } \\
\text { Unit/team members act autonomously }\end{array}$ \\
\hline
\end{tabular}


Table 4. The distribution of activities and resources in different types of groups.

\begin{tabular}{|c|c|c|c|c|}
\hline & \multicolumn{2}{|c|}{ Exploring and evaluating ideas and opportunities } & \multicolumn{2}{|l|}{ Mobilizing change } \\
\hline Group type & Description of activity & $\begin{array}{l}\text { Typical resources } \\
\text { related to activity }\end{array}$ & Description of activity & $\begin{array}{l}\text { Typical resources related } \\
\text { to activity }\end{array}$ \\
\hline $\begin{array}{l}\text { Strategic groups } \\
(\text { Cases } 1-5)\end{array}$ & $\begin{array}{l}\text { Fitting ideas and } \\
\text { opportunities from different } \\
\text { fields to the existing } \\
\text { business and estimating their } \\
\text { implications (Centralized) }\end{array}$ & $\begin{array}{l}\text { Knowledge of different } \\
\text { service areas } \\
\text { Knowledge of strategy } \\
\text { and resources } \\
\text { Expertise and experience } \\
\text { in the fields }\end{array}$ & $\begin{array}{l}\text { Making decisions, delegating } \\
\text { development responsibilities, } \\
\text { negotiating with customers, } \\
\text { managing implementation } \\
\text { processes (Centralized) }\end{array}$ & $\begin{array}{l}\text { Authority } \\
\text { Industry contacts } \\
\text { Customer contacts }\end{array}$ \\
\hline $\begin{array}{l}\text { Centralized groups } \\
\text { (Cases 6-8) }\end{array}$ & $\begin{array}{l}\text { Fitting ideas from other } \\
\text { fields and contexts to the } \\
\text { unit/team in question } \\
\text { (Centralized) }\end{array}$ & $\begin{array}{l}\text { Knowledge of the unit's } \\
\text { strategy } \\
\text { Professional expertise } \\
\text { and broad experience in } \\
\text { the service area }\end{array}$ & $\begin{array}{l}\text { Making decisions, persuading } \\
\text { colleagues/managers, delegating } \\
\text { development responsibilities, } \\
\text { negotiating with customers } \\
\text { (Centralized) }\end{array}$ & $\begin{array}{l}\text { Authority } \\
\text { Autonomy (in relation to } \\
\text { firm/unit) } \\
\text { Industry contacts } \\
\text { Customer contacts }\end{array}$ \\
\hline $\begin{array}{l}\text { Managed groups } \\
\text { (Cases 9-12) }\end{array}$ & $\begin{array}{l}\text { Reflecting on opportunities } \\
\text { and challenges in the current } \\
\text { practices and estimating } \\
\text { unit-wide improvement } \\
\text { possibilities } \\
\text { (Decentralized) }\end{array}$ & $\begin{array}{l}\text { Knowledge of the unit's } \\
\text { strategy } \\
\text { Professional expertise } \\
\text { and practical experience } \\
\text { in service work }\end{array}$ & $\begin{array}{l}\text { Making decisions, persuading } \\
\text { colleagues/managers, delegating } \\
\text { development responsibilities, } \\
\text { negotiating with customers } \\
\text { (Centralized) }\end{array}$ & $\begin{array}{l}\text { Authority } \\
\text { Autonomy (in relation to } \\
\text { firm/unit) } \\
\text { Industry contacts } \\
\text { Customer contacts }\end{array}$ \\
\hline $\begin{array}{l}\text { Collective groups } \\
\text { (Cases 13-15) }\end{array}$ & $\begin{array}{l}\text { Estimating how the } \\
\text { unit/team could overcome } \\
\text { challenges and use ideas } \\
\text { from other fields } \\
\text { (Decentralized) }\end{array}$ & $\begin{array}{l}\text { Knowledge of the unit's } \\
\text { strategy } \\
\text { Professional expertise } \\
\text { and practical experience } \\
\text { in service work }\end{array}$ & $\begin{array}{l}\text { Making decisions, coordinating } \\
\text { change processes, negotiating } \\
\text { with customers (Decentralized) }\end{array}$ & $\begin{array}{l}\text { Autonomy (in relation to } \\
\text { firm/unit) } \\
\text { Industry contacts } \\
\text { Customer contacts }\end{array}$ \\
\hline $\begin{array}{l}\text { Dispersed groups } \\
\text { (Cases 16-19) }\end{array}$ & $\begin{array}{l}\text { Estimating how to improve } \\
\text { one's own practice in } \\
\text { upcoming customer cases } \\
\text { (Decentralized) }\end{array}$ & $\begin{array}{l}\text { Knowledge of the } \\
\text { customer's problem } \\
\text { Professional expertise } \\
\text { and practical experience } \\
\text { in service work }\end{array}$ & $\begin{array}{l}\text { Making project-specific decisions } \\
\text { and negotiating with customers } \\
\text { (Decentralized) }\end{array}$ & $\begin{array}{l}\text { Autonomy at work } \\
\text { Customer contacts }\end{array}$ \\
\hline
\end{tabular}


Table 5. Group types and the maturity of service areas.

\begin{tabular}{|c|c|c|c|c|c|c|c|c|}
\hline \multirow[b]{2}{*}{ Firm } & \multirow[b]{2}{*}{ Service areas } & \multirow{2}{*}{$\begin{array}{l}\text { Size } \\
\text { (personnel) }\end{array}$} & \multirow[b]{2}{*}{ Maturity } & \multicolumn{5}{|c|}{ Group type } \\
\hline & & & & Strategic** & Centralized & Managed & Collective & Dispersed \\
\hline DesCo & Workplace design & 10 & Low & $\mathrm{C} 1$ & & & $\mathrm{C} 13$ & C16b \\
\hline AcCo & Tax advisory services & 70 & Low & & $\mathrm{C} 7$ & $\mathrm{C} 9 \mathrm{a}, \mathrm{C} 10 \mathrm{a}$ & & \\
\hline AcCo & $\begin{array}{l}\text { Financial advisory } \\
\text { services }\end{array}$ & 60 & Low & & & $\mathrm{C} 9 \mathrm{~b}, \mathrm{C} 10 \mathrm{~b}$ & & \\
\hline AcCo & Risk advisory services & 60 & Low & & & $\mathrm{C} 9 \mathrm{c}, \mathrm{C} 10 \mathrm{c}$ & & \\
\hline EngCo & $\begin{array}{l}\text { Property management } \\
\text { consulting }\end{array}$ & 30 & Low & $\mathrm{C} 4$ & & $\mathrm{C} 11$ & $\mathrm{C} 14$ & \\
\hline BuildCo & Property development & 4 & Low & $\mathrm{C} 5$ & $\mathrm{C} 8 \mathrm{~b}$ & & & $\mathrm{C} 19 \mathrm{c}$ \\
\hline DesCo & Sports venue design & 13 & Moderate & $\mathrm{C} 1$ & C6 & & & C16a \\
\hline DesCo & $\begin{array}{l}\text { Recreational venue } \\
\text { design }\end{array}$ & 20 & Moderate & $\mathrm{C} 1$ & & & & $\mathrm{C} 16 \mathrm{c}$ \\
\hline AdCo & Event marketing & 15 & Moderate & $\mathrm{C} 2, \mathrm{C} 3$ & & & & $\mathrm{C} 17 \mathrm{~b}$ \\
\hline AdCo & Digital marketing & 8 & Moderate & $\mathrm{C} 2, \mathrm{C} 3$ & & & & $\mathrm{C} 17 \mathrm{c}$ \\
\hline BuildCo & $\begin{array}{l}\text { Infrastructure } \\
\text { consultancy }\end{array}$ & 55 & Moderate & $\mathrm{C} 5$ & C8a & & & $\mathrm{C} 19 \mathrm{~b}$ \\
\hline AdCo & Traditional marketing & 30 & High & $\mathrm{C} 2, \mathrm{C} 3$ & & & & $\mathrm{C} 17 \mathrm{a}$ \\
\hline EngCo & Electrical design & 40 & High & $\mathrm{C} 4$ & & & & $\mathrm{C} 18 \mathrm{a}$ \\
\hline EngCo & HVAC design & 50 & High & $\mathrm{C} 4$ & & & & $\mathrm{C} 18 \mathrm{~b}$ \\
\hline BuildCo & $\begin{array}{l}\text { Construction } \\
\text { consultancy }\end{array}$ & 80 & High & $\mathrm{C} 5$ & & $\mathrm{C} 12$ & $\mathrm{C} 15$ & C19a \\
\hline
\end{tabular}

* Note that strategic groups C1-C5 span across service areas, and thus appear in several rows in this table. 
Structural and cultural conditioning

- Maturity of the service area and field

- Leadership style in the service area

- Personal histories of organizational members

T1

Distribution of resources to groups and their members

$\rightarrow$ Diachronic emergence of reflexive tencencies and bargaining power of individuals

$\rightarrow$ Synchronic emergence of individual-level agency from the relations between reflexivity

and bargaining power

Sociocultural action and group interaction

- Formation of temporary groups that pursue a particular development need

- Perceived distribution of individuals' agentic properties in relation to the development need $\rightarrow$ structuring and interactions within groups

T2

$\rightarrow$ Synchronic emergence of (temporary) collective agency from the members properties and their relations

$\rightarrow$ Actualization of collective agency and selective actualization of individuals' agency in group interactions

Structural elaboration and group elaboration

- Changes in the service area and organization

$\rightarrow$ Changes in resource distributions

$\rightarrow$ Changes in individuals'bargaining power and reflexivity

$\rightarrow$ Diachronic emergence of individual agency at the beginning of new morphogenetic cycle

Figure 2. Emergence of transformative agency in the studied cases 